Article

\title{
Co-Processed Olive Oils with Thymus mastichina L.-New Product Optimization
}

\author{
Fátima Peres $^{1,2}\left(\mathbb{D}\right.$, Marta Roldão $^{2}$, Miguel Mourato ${ }^{2} \mathbb{D}$, Luisa L. Martins ${ }^{2}$ and Suzana Ferreira-Dias $^{2, *(D)}$ \\ 1 Instituto Politécnico de Castelo Branco, Escola Superior Agrária, 6000-909 Castelo Branco, Portugal; \\ fperes@ipcb.pt \\ 2 LEAF, Linking Landscape, Environment, Agriculture and Food, Instituto Superior de Agronomia, \\ Universidade de Lisboa, 1349-017 Lisbon, Portugal; marta_roldao97@hotmail.com (M.R.); \\ mmourato@isa.ulisboa.pt (M.M.); luisalouro@isa.ulisboa.pt (L.L.M.) \\ * Correspondence: suzanafdias@mail.telepac.pt
}

Citation: Peres, F.; Roldão, M.; Mourato, M.; Martins, L.L.; Ferreira-Dias, S. Co-Processed Olive Oils with Thymus mastichina L.-New Product Optimization. Life 2021, 11, 1048. https://doi.org/ 10.3390/life11101048

Academic Editor: Othmane Merah

Received: 29 August 2021

Accepted: 2 October 2021

Published: 6 October 2021

Publisher's Note: MDPI stays neutral with regard to jurisdictional claims in published maps and institutional affiliations.

Copyright: (c) 2021 by the authors. Licensee MDPI, Basel, Switzerland. This article is an open access article distributed under the terms and conditions of the Creative Commons Attribution (CC BY) license (https:// creativecommons.org/licenses/by/ $4.0 /)$.
Abstract: Olive co-processing consists of the addition of ingredients either in the mill or in the malaxator. This technique allows selecting the type of olives, the ingredients with the greatest flavoring and bioactive potential, and the technological extraction conditions. A new product-a gourmet flavored oil-was developed by co-processing olives with Thymus mastichina L. The trials were performed using overripe fruits with low aroma potential (cv. 'Galega Vulgar'; ripening index 6.4). Experimental conditions were dictated by a central composite rotatable design (CCRD) as a function of thyme $(0.4-4.6 \%, w / w)$ and water $(8.3-19.7 \%, w / w)$ contents used in malaxation. A flavored oil was also obtained by adding $2.5 \%$ thyme during milling, followed by $14 \%$ water addition in the malaxator (central point conditions of CCRD). The chemical characterization of the raw materials, as well as the analysis of the flavored and unflavored oils, were performed (chemical quality criteria, sensory analysis, major fatty acid composition, and phenolic compounds). Considering chemical quality criteria, the flavored oils have the characteristics of "Virgin Olive Oil" (VOO), but they cannot have this classification due to legislation issues. Flavored oils obtained under optimized co-processing conditions (thyme concentrations $>3.5-4.0 \%$ and water contents varying from 14 to $18 \%$ ) presented higher phenolic contents and biologic value than the non-flavored VOO. In flavored oils, thyme flavor was detected with high intensity, while the defect of "wet wood", perceived in VOO, was not detected. The flavored oil, obtained by T. mastichina addition in the mill, showed higher oxidative stability $(19.03 \mathrm{~h})$ than the VOO and the co-processed oil with thyme addition in the malaxator $(14.07 \mathrm{~h})$, even after six-month storage in the dark (16.6 vs. $10.3 \mathrm{~h}$ ).

Keywords: co-extraction; flavored oil; response surface methodology; phenols; thyme

\section{Introduction}

Virgin olive oil is the oil extracted from the fruits of the olive tree (Olea europaea L.) using exclusively mechanical extraction techniques under conditions that will not affect the original composition of the oil. In the last decades, many research studies have shown that virgin olive oil has bioactive properties with impacts on health, particularly in preventing cardiovascular diseases, cancer, diabetes, and neurodegenerative diseases [1-4]. These benefits are due not only to its fatty acid profile, especially to the high content in oleic acid, but also to the presence of several bioactive compounds [1,5-7]. This evidence led the European Union, in 2006, to approve nutritional and health claims for virgin olive oil (VOO), to be included on the label. They concern monounsaturated fatty acids, oleic acid, and unsaturated acids, vitamin E, and more recently, in 2012, polyphenols in the olive oil $[8,9]$.

Most of the Portuguese olive orchards in organic production are predominantly rainfed and very much based on autochthonous varieties, which are characterized by unique sensory properties. Combining these aspects with the consumers' trend towards products 
offering health benefits, the great challenge to promote and protect this type of olive orchard is related to the production of high-quality oils (extra virgin olive oil-EVOO) and novel added-value products. Labeling these products with nutrition and health claims is very important in terms of consumers' acceptance and choice. In recent years, innovation in olive oils has included flavoring with different ingredients, with the aim of improving their sensory and nutritional properties, as well as shelf life. Thus, this type of product is highly appreciated, especially among consumers outside the Mediterranean countries, reaching values above EUR 50 per liter. The added compounds may have several health benefits due to the presence of natural bioactive substances with antioxidant and/or antimicrobial properties and may contribute to increasing olive oil's resistance to oxidation [10]. Vegetables, aromatic herbs, fruits, nuts, essential oils, and spices are the most common ingredients used, added either as an infusion, ethanolic extracts of essential oils, or by co-processing [10-16].

Co-processing, also known as co-extraction, is an alternative method to infusion techniques, or to the addition of ethanolic extracts, to obtain flavored or enriched oils. It consists of the addition of ingredients, for example, fruits or aromatic plants, during milling or in the malaxation step of the olive oil extraction process. This technique allows for selecting both the type of olives (e.g., cultivar and ripening stage), the ingredient(s) with the greatest flavoring and/or bioactive potential, as well as the extraction conditions. Moreover, this method does not need the filtration step, conversely to when infusion is performed. For olive oils from organic farming, the production of co-processed oils can be an opportunity for differentiation, creating products mainly for the non-traditional consumer market. Although studies of co-processing are scarce, some show that using co-extraction with the addition of lemon, bergamot, rosemary, thyme, basil, and oregano causes positive sensory notes [10,13,17-19]. In addition, the use of citrus fruits or their peels in co-extraction increases the antioxidant activity of olive oil and its nutritional value $[18,20,21]$. The use of spices in co-malaxation increases the antioxidant activity of olive oils compared to the infusion technique [13]. Tomato by-products are also used in co-milling to enrich olive oils with lycopene [22].

Thymus mastichina L. (T. mastichina) is an Iberian endemic thyme used in the food industry as a condiment and herbal infusion and as a source of essential oil for the cosmetics industry $[23,24]$. It is also known as mastic thyme, Spanish marjoram, or white thyme. Traditionally, it was used for treating digestive, respiratory, and rheumatic disorders [25]. The major compounds in the essential oil of T. mastichina are 1,8-cineol (58.8-64.1\%) and $\alpha$-terpineol (5.6\%) [26]. The main phenolic compounds identified in T. mastichina extracts are rosmarinic acid, methoxysalicylic acid, apigenin, kaempferol, luteolin, chlorogenic acid, cafeic acid, and derivatives of luteolin and apigenin [24,27]. Thus, the selection of this species of thyme for co-extraction trials is based on the use of an endogenous plant as well as on its potential, not only in terms of sensory attributes but also for improving the biological value and oxidative stability of enriched flavored oils. Therefore, the aim of this study is to develop a new value-added product, a gourmet flavored oil, based on co-processing overripe healthy 'Galega Vulgar' olives, with low intensity of fruity aroma and low amounts of bioactive phenolic compounds, and Thymus mastichina L. from organic farming. The effect of the addition of dried thyme, either in olive milling or in malaxation, is investigated. It is expected to obtain a gourmet oil with thyme flavor and, if possible, improved bioactivity and shelf-life. According to our knowledge, this is the first study on co-extraction of olives with this species of thyme and process optimization using response surface methodology. 


\section{Materials and Methods}

\subsection{Biological Material}

Portuguese olive fruits of 'Galega Vulgar' cultivar used in the present study were produced in a rain-fed olive grove situated in the Beira Baixa region $\left(39^{\circ} 50^{\prime} \mathrm{N}, 7^{\circ} 42^{\prime} \mathrm{W}\right)$, Portugal. 'Galega Vulgar' fruits were picked in January 2021, with a ripening index (RI) of 6.4 and an average weight of $2.5 \pm 0.1 \mathrm{~g}$ per fruit with a very low water content $(42.31 \% \pm$ $0.21 \%$ ), were used for the co-processing experiments with thyme addition in the malaxation operation. 'Galega Vulgar'olives with a RI of 6.2 were used for the co-processing trials with the addition of thyme in the mill. Dried Thymus mastichina L. was purchased from Ervas de Zoé, Ladoeiro, Portugal, and was produced according to organic farming (OF) guidelines.

\subsection{Milling of Thymus Mastichina L. and Particle Size Classification}

The dried plants of T. mastichina were submitted to milling (hammer mill PX-MFC90D from Kinematic, Switzerland, exit grid of $2 \mathrm{~mm}$ opening). Sieve analysis was performed to classify the particles according to their size, using five sieves of Tyler equivalent series $(10,28,35,60$, and 140 mesh, equivalent to opening sieves of $1.68,1,0.42,0.25$, $0.106 \mathrm{~mm}$, respectively)

\subsection{Co-Processing}

Flavored oils were obtained in a laboratory oil mill (Abencor analyzer; MC2 Ingenieria y Sistemas S.L., Seville, Spain), comprising a hammer mill, a malaxation unit, and a cylindrical bowl centrifuge. The olives (c.a. $10 \mathrm{~kg}$ ) were crushed at $3000 \mathrm{rpm}$, using a $5 \mathrm{~mm}$ grid in the mill.

Co-processing experiments with thyme addition in the malaxator were performed following a central composite rotatable design (CCRD) as a function of the contents of thyme and water [28,29]. In each trial, $0.5 \mathrm{~kg}$ of olives was used. In this design, the five levels tested for thyme and water concentration were between 0.4 and $4.6 \%(w / w)$ and between 8.3 and $19.7 \%(w / w)$, respectively (Table 1$)$. Water and thyme were added at the beginning of the malaxation step, carried out at $28-30{ }^{\circ} \mathrm{C}$ for $30 \mathrm{~min}$. Paste centrifugation was performed at $3500 \mathrm{rpm}$ for $1 \mathrm{~min}$. After centrifugation, the water traces in the oil were removed with anhydrous sodium sulfate, which was removed by filtration through a cellulose filter (Whatman 41) [30]. After, the oils were collected in amber flasks and stored at $4{ }^{\circ} \mathrm{C}$ until analysis.

The combined effects of the concentrations of T. mastichina (Tm) and of water (W) on the oil extraction yield, total phenols, chlorophyll pigments, major fatty acid composition, as well as on chemical quality criteria parameters (acidity, peroxide value, and UV absorbances) of the extracted oils, were investigated by response surface methodology (RSM). RSM allows finding the optimal conditions with a smaller number of experiments than the conventional approach (one variable at a time, OVAT), with the same precision as OVAT and with the advantage of giving information about possible interactions between the variables, which is not possible following the OVAT approach [28,29].

Another set of experiments was carried out with a different batch of olives $(\mathrm{RI}=6.2)$ with the addition of thyme in the mill, at the concentration of the central point of the CCRD $(2.5 \%, w / w)$. Water was added to the malaxator at a concentration of $14 \%$ (conditions of the central point). The extraction yield was calculated as previously described [31]. Chemical and sensory analyses were performed within one week after extraction. 
Table 1. CCRD followed in the experiments for co-processing as a function of the amounts of thyme and water added in malaxation. Experiment $\mathrm{N}^{\mathrm{o}} 14$ (control) corresponds to the virgin olive oil obtained under the same extraction conditions as flavored oils.

\begin{tabular}{|c|c|c|c|c|c|}
\hline Experimental Points & Experiment Number & $\begin{array}{c}\text { [Thyme] } \\
\text { Coded Value }\end{array}$ & $\begin{array}{c}\text { [Water] } \\
\text { Coded Value }\end{array}$ & $\begin{array}{c}\text { [Thyme] }(\%) \\
\text { Decoded Values }\end{array}$ & $\begin{array}{c}\text { [Water] (\%) } \\
\text { Decoded Values }\end{array}$ \\
\hline \multirow{4}{*}{ Factorial points } & 1 & -1 & -1 & 1 & 10 \\
\hline & 2 & -1 & 1 & 1 & 18 \\
\hline & 3 & 1 & -1 & 4 & 10 \\
\hline & 4 & 1 & 1 & 4 & 18 \\
\hline \multirow{4}{*}{ Star points } & 5 & $-\sqrt{2}$ & 0 & 0.4 & 14 \\
\hline & 6 & $\sqrt{2}$ & 0 & 4.6 & 14 \\
\hline & 7 & 0 & $-\sqrt{2}$ & 2.5 & 8.3 \\
\hline & 8 & 0 & $\sqrt{2}$ & 2.5 & 19.7 \\
\hline \multirow{5}{*}{ Central points } & 9 & 0 & 0 & 2.5 & 14 \\
\hline & 10 & 0 & 0 & 2.5 & 14 \\
\hline & 11 & 0 & 0 & 2.5 & 14 \\
\hline & 12 & 0 & 0 & 2.5 & 14 \\
\hline & 13 & 0 & 0 & 2.5 & 14 \\
\hline Control & 14 & _- & _ & - & 14 \\
\hline
\end{tabular}

\subsection{Shelf-Life Studies}

Flavored and unflavoured oil were stored in amber glass bottles at $22-23{ }^{\circ} \mathrm{C}$, in the dark, for 6-month shelf-life studies. These samples were analyzed as described in paragraph 2.6.

\subsection{Proximate Analysis of Olives and Thyme}

Samples (Galega olives after the milling process and thyme plants after milling (2.2)) were subjected to drying at $105 \pm 2{ }^{\circ} \mathrm{C}$ (Selecta Drying Oven, JP Selecta, Barcelona, Spain) until constant weight, in order to evaluate their moisture content. Fat content was determined by extraction from dried samples in a Soxtec System HT2 Extraction unit (Tecator $\mathrm{AB}$, Hoganas, Sweden), using petroleum ether as an organic solvent. For ash content assay, samples with an initial weight of around $0.5 \mathrm{~g}$ were placed in a muffle furnace at $550{ }^{\circ} \mathrm{C}$ (Heraeus Instruments, Hanau, Germany). After $24 \mathrm{~h}$, the final weight of the samples was obtained, and the ash content was determined. For protein content assay, nitrogen content $(\mathrm{N})$ was determined in dried samples according to the Kjeldahl method using $0.5 \mathrm{~g}$ of each sample (Velp Scientifica UDK 139, Usmate, Italy). The crude protein content was obtained using the conversion factor of 6.25. Mineral element content was determined as follows: approximately $0.4 \mathrm{~g}$ of each dried sample were ground in a mortar and weighed in a Teflon tube to which $3 \mathrm{~mL}$ of concentrated nitric acid (68\%) and $10 \mathrm{~mL}$ of concentrated hydrochloric acid $(37 \%)$ were added. The tubes were then placed in a digestion plate (DigiPrep MS, SCP Science, Quebec, QC, Canada) with a heating cycle to $95^{\circ} \mathrm{C}$ that lasted $1 \mathrm{~h}$ and remained at $95^{\circ} \mathrm{C}$ for $1 \mathrm{~h}$ more. After cooling at $20^{\circ} \mathrm{C}$, the samples were filtered into a $25 \mathrm{~mL}$ volumetric flask and the volume filled with distilled water. The quantification of the elements ( $\mathrm{Cu}, \mathrm{Zn}, \mathrm{Fe}, \mathrm{Mn}, \mathrm{Na}, \mathrm{K}, \mathrm{Ca}, \mathrm{Mg}, \mathrm{P}$, and S) was done with ICP-OES (Inductively coupled plasma optical emission spectroscopy, Thermo iCAP 7200, Thermo Fisher Scientific, Waltham, MA, USA). Appropriate standards were prepared from a stock solution $(100 \mathrm{mg} / \mathrm{L})$ containing the analyzed elements (SCP Science, PlasmaQUAL S22, Baie-D'Urfe, QC, Canada). Results were expressed as mg/kg dry matter (DW).

\subsection{Chemical and Sensory Characterisation of Flavored Oils}

Acidity (\% free fatty acids, \%FFA, expressed in oleic acid), peroxide value (PV), UV absorbances related with the formation of conjugated hydroperoxides $\left(\mathrm{K}_{232}\right)$ and secondary oxidation products $\left(\mathrm{K}_{270}\right)$, and the major fatty acids (C16:0, C18:0, C18:1, and C18:2) of 
oils were evaluated by NIR spectroscopy (MPA, Bruker Optics, Ettlingen, Germany). The calibration model B-Olive-Oil (Bruker Optics, Ettlingen, Germany) was used. Spectral information was obtained from olive oil samples, previously prepared obtained at $50{ }^{\circ} \mathrm{C}$ (IN600-A, Bruker, Ettlingen, Germany), in absorbance mode and at a wavelength of 1200 to $4000 \mathrm{~cm}^{-1}$, with $8 \mathrm{~cm}^{-1}$ resolution and 32 scans.

Total phenols were extracted by liquid-liquid microextraction and evaluated by VIS spectroscopy (JASCO 7800, Jasco Inc., Tokyo, Japan) according to Pizarro et al. [32], as previously described [33]. Results were expressed as milligram of gallic acid equivalent per kilogram of oil (mg GAE $/ \mathrm{kg}$ ). Chlorophyll pigments were assayed in accordance with the IUPAC method proposed by Pokorný et al. [34] using a single beam spectrophotometer (Biochrom Libra S21, Biochrom Ltd., Cambridge, UK) to evaluate the absorbances of oils at 630,670 , and $710 \mathrm{~nm}$ against air. The results were expressed as $\mathrm{mg}$ pheophytin a/ $\mathrm{kg}$ oil. All analyses were performed in triplicate.

Samples of flavored oils were also sensory evaluated by a trained panel [35]. A Quantitative Descriptive Analysis (QDA) was applied by using a profile sheet where an unstructured $10 \mathrm{~cm}$ length scale was used to mark the intensity of the descriptors [36]. This profile sheet mainly considered the positive attributes (e.g., orthonasal, retronasal, and gustative analysis) of the oils. If defects were found, it was necessary to identify them and quantify their intensity. Oxidative stability (OS) was measured using a Metrohm Rancimat model 670 (Metrohm, Herisau, Switzerland) (temperature of $120{ }^{\circ} \mathrm{C}$; airflow of $20 \mathrm{~L} \mathrm{~h}^{-1}$ ).

The profile of phenolic compounds was evaluated by high performance liquid chromatography (HPLC) according to the International Olive Council method with some modifications [37]. The phenolic compounds were recovered from the olive oil by liquid-liquid extraction using the procedure proposed by Pirisi et al. [38]. An Agilent 1100 HPLC system (Agilent, Santa Clara, CA, USA), consisting of a degasser, a quaternary pump, a column oven, an autosampler, and a UV detector, was used. The stationary phase was a Purospher C18 analytical column $(150 \mathrm{~mm} \times 3.9 \mathrm{~mm} \times 4 \mu \mathrm{m})$. The mobile phase consisted of solutions of (A) $0.2 \% \mathrm{H}_{3} \mathrm{PO}_{4}(v / v),(\mathrm{B})$ methanol, and (C) acetonitrile at a constant flow rate of $1 \mathrm{~mL} \mathrm{~min}^{-1}$. The gradient program used was the one indicated by the IOC document [37]. The identification of phenolic compounds was carried out using standards for gallic acid, hydroxytyrosol, tyrosol, vanillic acid, caffeic acid, vanillin, $p$-coumaric acid, o-coumaric acid, cinnamic acid, luteolin, apigenin, rosmarinic acid, kaempferol, and pinoresinol. Syringic acid was used as an internal standard. Standards of hydroxytyrosol, tyrosol, vanillic acid, vanillin, caffeic acid, ferulic acid, $o$-coumaric, $p$-coumaric, apigenin, rosmarinic acid were purchased from Sigma-Aldrich (St. Louis, MO, USA), oleuropein and luteolin from Extrasynthese (Genay, France), and pinoresinol from TCI Europe (Zwijndrecht, Belgium).

\subsection{Statistical Analysis}

The obtained results of CCRD, as well as ANOVA (post hoc Tukey test was used; $p \leq 0.05$ ), were analyzed using the software Statistica, version 7, from Statsoft, Tulsa, OK, USA. The linear effects, as well as the quadratic effects of each factor (variable) tested (water and thyme concentrations) and of their linear interactions, on each response (extraction yield, total phenols, and chlorophyll pigments contents) were calculated. The significance of each effect was evaluated by analysis of variance. A response surface, described by a first or a second-order polynomial equation, was fitted to each set of experimental results. The first and second-order coefficients of these equations were generated by regression analysis. The goodness of fit of the polynomial models was evaluated by the coefficient of determination $\left(R^{2}\right)$ and adjusted $R^{2}[28,29]$.

\section{Results and Discussion}

\subsection{Proximate Analysis of Olives and Thyme}

The results for moisture, fat, ash, protein, and mineral elements of olives and T. mastichina are presented in Table 2. The low moisture content of the olives highlights the need to perform the optimization of water addition in the malaxation trials, in combination with thyme 
addition. Galega olives and thyme fat contents (DW) are in accordance to Peres et al. [6] and to Barros et al. [39], respectively. In turn, ash and protein contents of thyme are higher than the values reported by Barros et al. [39]. For mineral composition, both materials have high contents of $\mathrm{K}$ (16.04 and $13.82 \mathrm{~g} / \mathrm{kg}$, in olives and thyme, respectively) and Ca (3.29 and $11.11 \mathrm{~g} / \mathrm{kg}$ in olives and thyme, respectively). However, no references on the mineral content in T. mastichin a were found. The results obtained in our study are very different from those observed by Kassegn and Mekelle [40] for lemon thyme, where the microelement contents were $0.734,1.630,16.41,0.106 \mathrm{mg} \mathrm{kg}^{-1}$ for $\mathrm{P}, \mathrm{Cu}, \mathrm{Fe}$, and $\mathrm{Mn}$, respectively. However, Kuçukbay and Kuyumcu [41] found values ranging from $6.5-14.90 \mathrm{mg} / \mathrm{kg}$ for $\mathrm{Cu}, 8.470-18.187 \mathrm{~g} / \mathrm{kg}$ for $\mathrm{K}$, and $8.383-25.570 \mathrm{~g} / \mathrm{kg}$ for $\mathrm{Ca}$, in other thyme species from Turkey, which are similar to the values obtained in the present study.

Table 2. Proximate analysis (DW) of olives and Thymus mastichina L.

\begin{tabular}{cccc}
\hline Parameter & Unit & Olives & T. mastichina \\
\hline Moisture & $(\%)$ & $42.31 \pm 0.21$ & $6.30 \pm 0.04$ \\
\hline Fat & $(\%)$ & $39.62 \pm 0.82$ & $3.08 \pm 0.01$ \\
\hline Ash & $(\%)$ & $3.67 \pm 0.59$ & $5.35 \pm 0.06$ \\
\hline Protein & $(\%)$ & $5.00 \pm 0.62$ & $7.79 \pm 0.15$ \\
\hline $\mathrm{Cu}$ & & $9.2 \pm 1.3$ & $10.1 \pm 1.1$ \\
$\mathrm{Zn}$ & & $19.8 \pm 3.0$ & $83.2 \pm 18.5$ \\
$\mathrm{Fe}$ & & $91.0 \pm 6.4$ & $218.5 \pm 4.5$ \\
$\mathrm{Mn}$ & & $154.8 \pm 7.6$ & $292.7 \pm 44.5$ \\
$\mathrm{Na}$ & & $16,040 \pm 199$ & $205.5 \pm 4.8$ \\
$\mathrm{~K}$ & $(\mathrm{mg} / \mathrm{kg})$ & $472 \pm 7$ & $13,822 \pm 1195$ \\
$\mathrm{Ca}$ & & $1199 \pm 17$ & $11,118 \pm 464$ \\
$\mathrm{Mg}$ & & $853 \pm 33$ & $2178 \pm 214$ \\
$\mathrm{P}$ & & & $1958 \pm 260$ \\
$\mathrm{~S}$ & & & $1854 \pm 107$ \\
\hline
\end{tabular}

\subsection{Particle-Size Analysis of Milled Thyme}

After milling, thyme particles, with dimensions smaller than $2 \mathrm{~mm}$, were separated by fractions using a set of 5 sieves. Figure 1 shows that c.a. $70 \%$ of ground material is formed by particles with dimensions between 1 and $1.68 \mathrm{~mm}$, corresponding to the fraction $10 / 18$ mesh. Only $0.2 \%$ of the particles have dimensions higher than 1.68 and smaller than $2 \mathrm{~mm}$, and $26.6 \%$ have dimensions smaller than $1 \mathrm{~mm}$. Therefore, the milled thyme used in co-processing presented very homogeneous particles concerning their size. These particles are big enough to facilitate their removal from the oil together with the olive pomace by centrifugation in olive oil extraction plants, avoiding emulsion formation and oil loss.

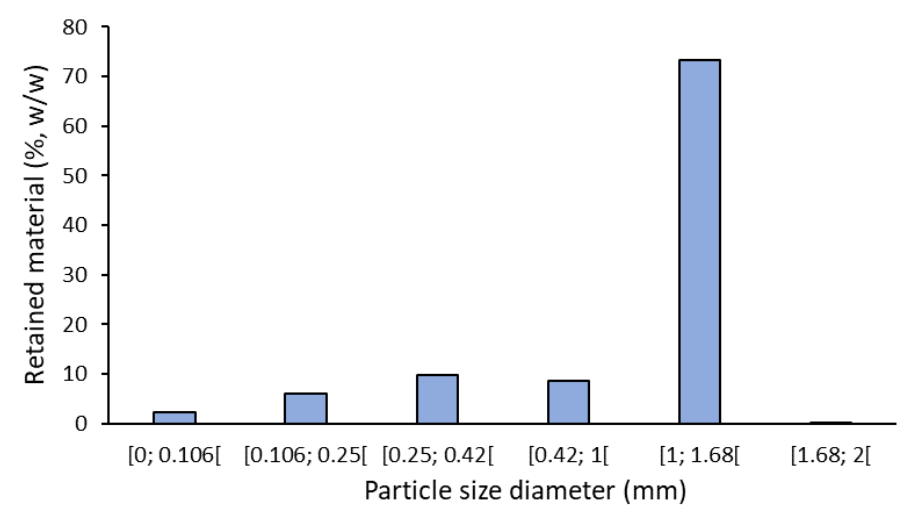

Figure 1. Histogram of different granulometric fractions of milled thyme. 


\subsection{Optimization of Co-Processing Conditions}

In the 'Galega' cultivar, the oil yield obtained without thyme addition was $10.6 \%$. In CCRD experiments, extraction yields in the presence of thyme varied from 5.1 to $10.7 \%$. Thus, except for experiment 2 (1\% thyme and $18 \%$ water), where $10.7 \%$ oil yield was obtained, the extraction yields obtained in the presence of thyme were lower than in the blank trial.

The statistical analysis of the oil yields showed that the addition of T. mastichina had a significant negative linear effect $(p=0.014)$ on oil extraction. It means that an increase in thyme concentration in the malaxation step will promote a decrease in extraction yield. This decrease may be ascribed to oil adsorption to the lignocellulosic material of thyme during malaxation operation, hindering mechanical oil extraction. A similar situation was referred by other authors, which was explained by an absorption/adsorption process [42,43]. For water addition, a positive linear effect was found $(p=0.05)$, meaning that an increase in water concentration will improve the extraction yield. A decrease in the viscosity of olive paste due to the presence of water may help oil extraction since diffusion is promoted. No significant quadratic effect of water and of the interaction effect of thyme and water addition was observed on oil yield. The negative quadratic effect of thyme $(p>0.05)$ was important enough to be retained in the response surface model. Its removal causes a great lack of fit of the model. In experimental design analysis, it is better to retain a "nonsignificant" effect $(p>0.05)$ in the model than to remove an important one [28]. Figure 2 shows the response surface fitted to oil extraction yield, $Y$, as a function of thyme $(\mathrm{Tm} ; \%, w / w)$ and water $(W ; \%, w / w)$ concentrations. This is a convex surface described by the following second-order polynomial Equation (1):

$$
Y=6.93+0.335 T m-0.239 \mathrm{Tm}^{2}+0.221 \mathrm{~W}
$$

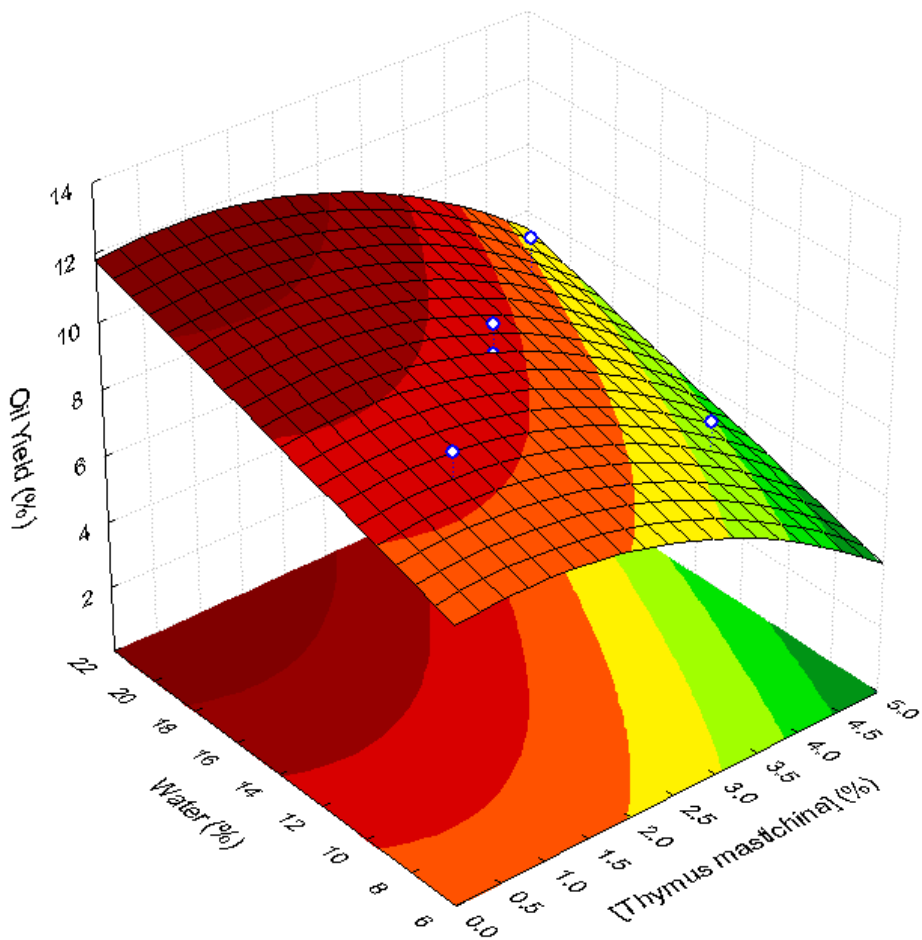

Figure 2. Response surface describing oil yield (\%) as a function of water $(\%, w / w)$ and thyme concentration $(\%, w / w)$, added to 'Galega Vulgar' fruits during malaxation.

This model presents a good fit to the experimental points since it has a determination coefficient, $R^{2}$, of 0.69 and an adjusted determination coefficient $\left(R^{2}\right.$ Adj $)$ of 0.59 . Therefore, $69 \%$ of the experimental results are explained by this model. 
Higher oil yields were observed for higher water contents and lower thyme concentrations (Figure 2).

\subsection{Characterization of Flavored Oils}

The results of chemical quality criteria (acidity, PV, and UV absorbances) and major fatty acid composition (C16:0; C18:1; C18:2, and C18:3) of (i) the flavored oils obtained from CCDR trials, (ii) of one flavored oil obtained by co-processing with thyme addition during milling, and (iii) of the virgin olive oil obtained under the same extraction conditions without thyme addition, are presented in Table 3. The variation observed in chemical quality criteria of flavored oils, acidity $(0.17-0.21 \%), \mathrm{PV}\left(4.2-4.9\right.$ meq $\left.\mathrm{O}_{2} \mathrm{~kg}^{-1}\right), \mathrm{K}_{232}$ (1.54-1.63), and $\mathrm{K}_{270}(0.11-0.15)$, is not significant. This shows that the co-processing with T. mastichina did not affect the quality of the flavored oils obtained. Moreover, a similar behavior was observed concerning the major fatty acid contents: palmitic acid varied from 11.54 to $12.22 \%$; oleic acid ranged from 77.00 to $77.42 \%$; linoleic acid varied from 4.56 to $5.06 \%$ and linolenic acid from 0.5 to $0.8 \%$. In addition, flavored oils obtained by co-processing, either with thyme addition in the hammer mill or in the malaxator, have similar quality values and fatty acid composition. Other authors have stated that when the initial indices are relatively high, the obtained flavored oils may present quality parameters values above the legal limit for EVOO [17,44]. This was not observed in our study.

Table 3. Results of acidity (\% oleic acid), peroxide value (meq $\left.\mathrm{O}_{2} \mathrm{~kg}^{-1}\right)$, $\mathrm{UV}$ absorbances $\left(\mathrm{K}_{232}, \mathrm{~K}_{270}\right)$, palmitic acid (\%) (C16:0), oleic acid (\%) (C18:1), linoleic acid (\%) (C18:2), and linolenic acid (\%) (C18:3) (conditions of each experiment are shown in Table 1; experiment 14 corresponds to the co-processed flavored oil obtained by adding thyme in the hammer mill; experiment 15 is the VOO extracted from the same fruits without thyme addition, i.e., the control).

\begin{tabular}{ccccccccc}
\hline Experiment & Acidity & PV & $\mathbf{K}_{\mathbf{2 3 2}}$ & $\mathbf{K}_{\mathbf{2 7 0}}$ & $\mathbf{C 1 6 : 0}$ & $\mathbf{C 1 8 : 1}$ & $\mathbf{C 1 8 : 2}$ & $\mathbf{C 1 8 : 3}$ \\
\hline 1 & 0.17 & 4.5 & 1.54 & 0.13 & 11.59 & 77.03 & 5.06 & 0.48 \\
2 & 0.18 & 4.3 & 1.57 & 0.11 & 11.54 & 76.99 & 5.00 & 0.58 \\
3 & 0.19 & 4.5 & 1.60 & 0.13 & 12.04 & 77.31 & 4.73 & 0.76 \\
4 & 0.21 & 4.3 & 1.59 & 0.12 & 12.06 & 77.21 & 4.66 & 0.75 \\
5 & 0.18 & 4.2 & 1.58 & 0.11 & 11.59 & 77.09 & 4.86 & 0.59 \\
6 & 0.18 & 4.7 & 1.61 & 0.15 & 12.22 & 77.42 & 4.56 & 0.82 \\
7 & 0.21 & 4.7 & 1.62 & 0.14 & 11.85 & 77.07 & 4.85 & 0.67 \\
8 & 0.17 & 4.3 & 1.60 & 0.12 & 11.97 & 77.10 & 4.63 & 0.67 \\
9 & 0.18 & 4.5 & 1.61 & 0.14 & 11.74 & 77.28 & 4.57 & 0.70 \\
10 & 0.17 & 4.9 & 1.61 & 0.14 & 11.87 & 77.16 & 4.73 & 0.72 \\
11 & 0.19 & 4.2 & 1.61 & 0.14 & 11.93 & 77.04 & 4.73 & 0.70 \\
12 & 0.18 & 4.7 & 1.63 & 0.14 & 11.97 & 77.08 & 4.77 & 0.71 \\
13 & 0.18 & 4.6 & 1.61 & 0.14 & 11.88 & 77.14 & 4.70 & 0.73 \\
\hline 14 (hammer mill) & 0.11 & 4.5 & 1.72 & 0.18 & 11.93 & 77.02 & 4.78 & 0.81 \\
\hline 15 (VOO-control) & 0.20 & 4.4 & 1.59 & 0.12 & 11.47 & 76.94 & 4.86 & 0.62 \\
\hline
\end{tabular}

The amounts of total phenolic compounds (TPH) in flavored oils varied from 60.7 to $141.6 \mathrm{mg} \mathrm{GAE} / \mathrm{kg}$ oil, while the VOO obtained without co-processing with thyme had a TPH of $71.4 \pm 6.8 \mathrm{mg}$ GAE $/ \mathrm{kg}$ oil. In fact, not all the flavored oils obtained by co-processing with T. mastichina added in the malaxator presented higher amounts of phenolic compounds than the original VOO. The low content of TPH in VOO is explained by the high ripening stage of the olives used, together with a relatively low TPH of Galega VOO, when compared to VOO from other cultivars at the same RI [6,45]. The flavored oil obtained under the conditions of the central point (Table 1: $2.5 \%$ thyme and $14 \%$ water) showed a TPH of $115.4 \pm 4.9 \mathrm{mg}$ GAE/ $\mathrm{kg}$ oil, corresponding to a TPH increase of $61.6 \%$ when compared with the non-flavored VOO. The co-processed flavored oil obtained by the addition of thyme in the mill, under the conditions of the central point, presented a $T P H$ of $189.66 \pm 6.8 \mathrm{mg}$ GAE $/ \mathrm{kg}$ oil, which represents an increase of $75 \%$ with respect to the original VOO. Thus, phenolic compounds extraction seems to be more efficient by 
co-processing with T. mastichina added in the milling than in the malaxation operation. These results show the importance of performing optimization trials before the addition of the flavoring agent.

Data analysis of CCRD showed that the content of phenolic compounds in flavored oils linearly increased with thyme concentration $(p=0.004)$ and with water added in the malaxator $(p=0.06)$. A significant negative quadratic effect of water concentration $(p=0.045)$, indicating a convex quadratic response as a function of this effect, was also found. No significant effects of thyme at quadratic level or of the interaction thyme $\mathrm{x}$ water were found. Therefore, a convex response surface, described by the following second-order polynomial, can be fitted to TPH (mg GAE $/ \mathrm{kg})$ as a function thyme $(\mathrm{Tm} ; \%, w / w)$ and water $(W ; \%, w / w)$ concentrations (Figure 3a), Equation (2):

$$
T P H=-98.19+12.91 T m+22.99 W-0.732 W^{2}
$$

The good fit of the model is demonstrated by high values of both $R^{2}(0.78)$ and $R^{2}$ Adj $(0.71)$.

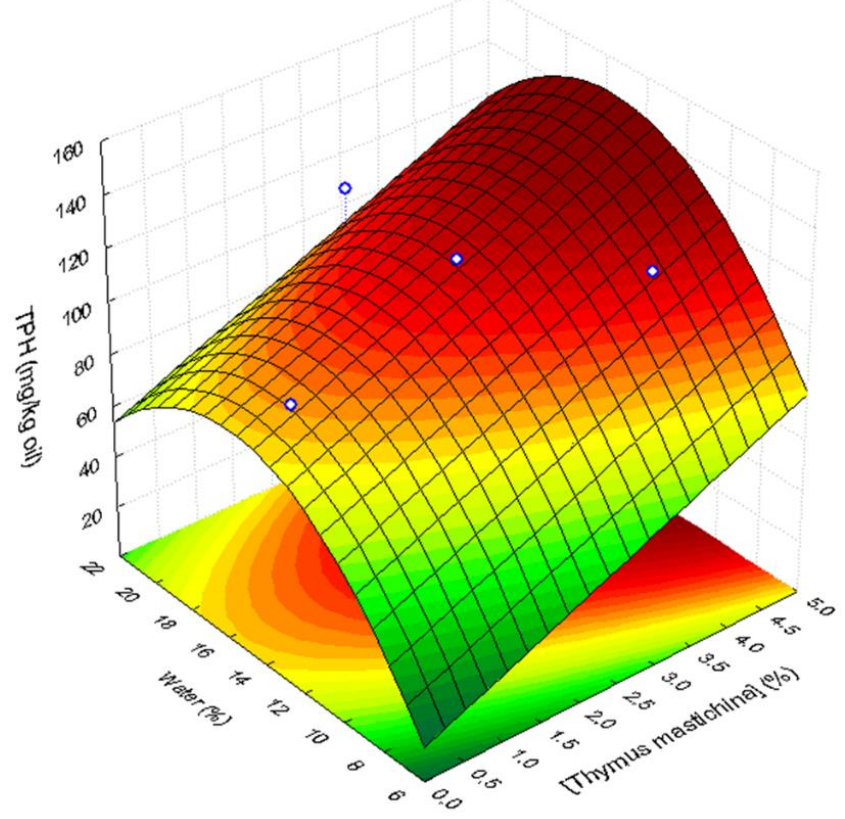

(a)

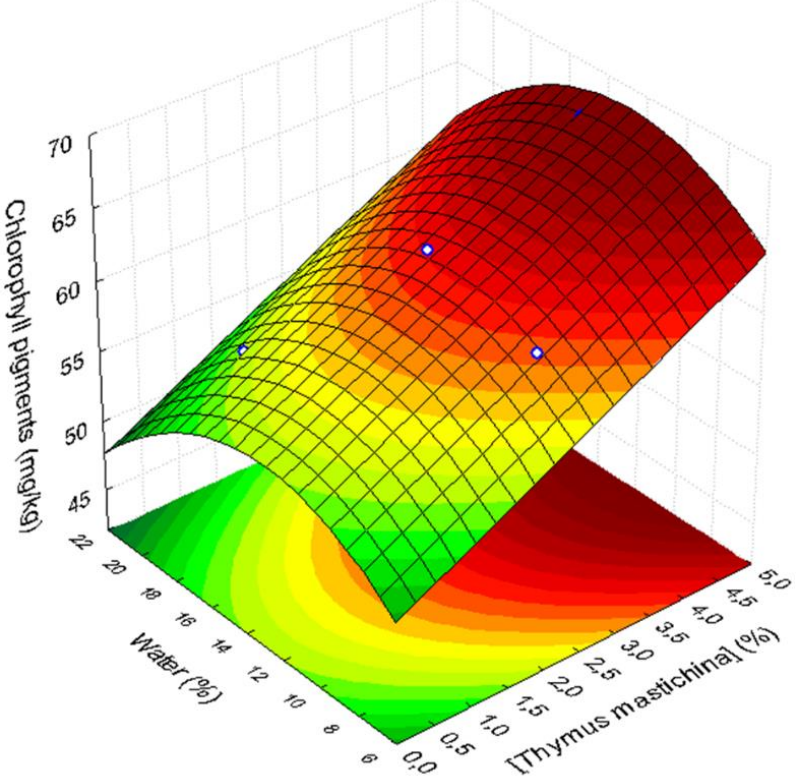

(b)

Figure 3. Response surfaces describing (a) total phenols (TPH; mg GAE/kg), and (b) chlorophyll pigments in flavored oils as a function of water $(\%, w / w)$ and thyme concentration $(\%, w / w)$, added to 'Galega Vulgar' fruits during malaxation.

Concerning chlorophyll pigments, their content in flavored oils with T. mastichina added in malaxation varied from 55.8 to $67.9 \mathrm{mg}$ pheophytin a/ $\mathrm{kg}$ oil against $49.4 \mathrm{mg}$ pheophytin a/kg oil in Galega VOO obtained from the same fruits. These results indicate that the migration of green pigments from the thyme to the oils occurs during co-extraction. In fact, CCRD data analysis showed that the content of chlorophyll pigments in the oils significantly depends on the thyme amount $\left(p=10^{-6}\right)$ added during malaxation, increasing with it. The water added in the malaxator showed to have a negative linear effect $(p=0.06)$ and a negative quadratic effect $(p=0.008)$ on green pigment extraction to the oils. Thus, chlorophyll pigments in flavored oils can be described by a convex surface as a function of thyme and water concentrations in pastes during malaxation (Figure 3b). This response surface is given by the following second-order polynomial equation where the amount of chlorophyll pigments $(C P ; \mathrm{mg} / \mathrm{kg}$ oil) is a function of thyme content $(\mathrm{Tm} ; \%, w / w)$ and water $(W ; \%, w / w)$ concentrations, Equation (3):

$$
C P=39.65+2.70 T m+2.39 W-0.092 W^{2}
$$


This model has a very good fit to the experimental results $\left(R^{2}=0.96 ; R^{2}\right.$ Adj $\left.=0.94\right)$.

Figure 3 shows that both TPH and chlorophyll pigments are described by similar shape convex response surfaces. The highest TPH values are obtained for co-processing with thyme concentrations higher than c.a. $3.5-4.0 \%$ and water contents in the range c.a. $14-18 \%$. The highest pigment contents are also obtained with thyme concentrations higher than c.a. $3.5 \%$ and water content of the pastes between 10 and $18 \%$. Conversely, the highest extraction yields are observed for thyme contents lower than $2.5 \%$ and when high water contents are used $(>18 \%)$ (Figure 2 ).

According to several authors, the addition of thyme (T. vulgaris) in olive oil increases the TPH [46,47], especially when the co-extraction technique is used [19]. The presence of high amounts of water in olive pastes during malaxation has been related to the loss of hydrophilic phenols in the water phase $[1,48]$. Therefore, in our study, the production of high-quality flavored oils enriched with bioactive phenolic compounds extracted from T. mastichina was obtained under conditions that will conduct to lower oil extraction yields. The use of RSM showed to be a useful tool to find the best operation conditions for flavored oil production by co-extraction. The evaluation of the profiles of oil yield, TPH, and chlorophylls in oils obtained under different co-extraction conditions (water and thyme concentrations) was only possible via the visual observation of each response surface fitted to each data set. The optimal co-extraction conditions were chosen from the information shown in these response surfaces.

\subsection{Shelf-Life Studies: Quality, Phenol Composition, Sensory Analysis, and Oxidative Stability}

The VOO and flavored oil samples obtained by co-processing with T. mastichina, added either in the malaxation or in milling operations, under the conditions of the central point of the CCRD (Table 1), were submitted to shelf-life studies. After 6 months of storage in the dark at $22-23^{\circ} \mathrm{C}, \mathrm{VOO}$ and flavored oils were assayed for their chemical parameters and sensory properties. No significant differences were observed among VOO and flavored oils in terms of quality parameters and fatty acid composition (Table 4). Moreover, for each quality parameter, no significant differences were observed between the initial values and those obtained after 6 months of storage, except for PV, which showed around a $66 \%$ increase in stored oils. This indicates that, after 6 months of storage in the dark, oil oxidation was at the initial induction stage of hydroperoxide formation. Along this storage period, TPH and chlorophyll pigments decreased 8.6 and $7.6 \%$, respectively.

Table 4. Results of acidity (\% oleic acid), peroxide value (meq $\left.\mathrm{O}_{2} \mathrm{~kg}^{-1}\right)$, UV absorbances $\left(\mathrm{K}_{232}, \mathrm{~K}_{270}\right)$, palmitic acid (\%) $(\mathrm{C} 16: 0)$, oleic acid (\%) (C18:1) and linoleic acid (\%) (C18:2) of the co-processed flavored oils obtained by adding thyme in the malaxator (experiments 9-13. corresponding to the central point of Table 1) or in the hammer mill (experiment 14); and of the virgin olive oil extracted from the same fruits without thyme addition (experiment 15), after 6 months storage at $22-23{ }^{\circ} \mathrm{C}$ in the dark.

\begin{tabular}{cccccccccc}
\hline Experiment & Acidity & PV & $\mathbf{K}_{\mathbf{2 3 2}}$ & $\mathbf{K}_{\mathbf{2 7 0}}$ & $\mathbf{C 1 6 : 0}$ & $\mathbf{C 1 8 : 1}$ & $\mathbf{C 1 8 : 2}$ & $\mathbf{C 1 8 : 3}$ & TPH \\
\hline 9 & 0.21 & 7.39 & 1.74 & 0.18 & 11.90 & 2.60 & 4.78 & 0.61 & 120.08 \\
10 & 0.20 & 7.07 & 1.74 & 0.16 & 11.84 & 2.58 & 4.92 & 0.58 & 108.19 \\
11 & 0.23 & 6.89 & 1.76 & 0.16 & 11.88 & 2.60 & 4.94 & 0.60 & 97.33 \\
12 & 0.22 & 7.65 & 1.78 & 0.17 & 11.95 & 2.63 & 4.96 & 0.63 & 107.13 \\
13 & 0.22 & 7.58 & 1.77 & 0.16 & 11.83 & 2.57 & 4.97 & 0.9 & 99.28 \\
\hline 14 (hammer mill) & 0.25 & 6.7 & 1.78 & 0.19 & 11.83 & 2.62 & 4.62 & 0.70 & 158.60 \\
\hline 15 (VOO-control) & 0.25 & 7.5 & 1.78 & 0.15 & 11.59 & 2.45 & 5.14 & 0.50 & 69.42 \\
\hline
\end{tabular}

In order to identify the phenols that migrated from the T. mastichina to the oils, increasing their bioactivity, an HPLC profile at $280 \mathrm{~nm}$ (all phenol compounds identified by standards), $320 \mathrm{~nm}$ ( $p$-coumaric acid), and $360 \mathrm{~nm}$ (flavonoids) was performed. The chromatographic phenolic profiles at $280 \mathrm{~nm}$ of thyme-flavored oils, compared to unflavored VOO, are shown in Figure 4. 


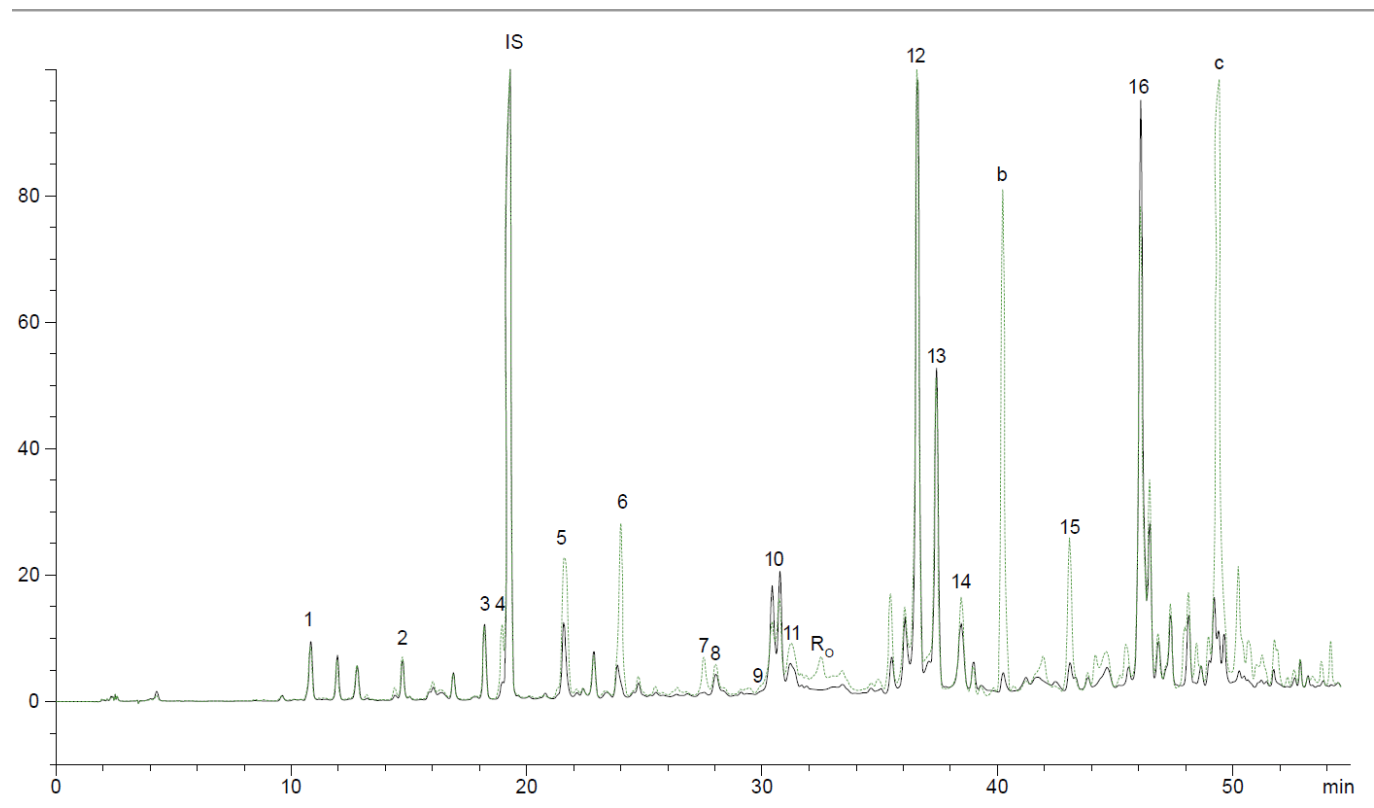

Figure 4. HPLC-RP-VWD $280 \mathrm{~nm}$ phenolic profile of the unflavored VOO (continuous line) and flavored oil (dotted line). (1-hydroxytyrosol; 2-tyrosol; 3-vanilic acid; IS-Internal standard (syringic acid) 4-caffeic acid; 5-vanillin; 6- $p$ coumaric acid; 7-unknown; 8-luteolin-7-glucosid; 9—o-coumaric acid; 10—3,4-DHPEA-EDA (literature); 11—oleuropein; Ro- Rosmarinic acid; 12—pinoresinol; 13—cinnamic acid 14-luteolin; 15—apigenin; 16— $p$-HPEA-EA (literature); b and c-unknown).

In our study, as a result of the co-extraction with T. mastichina, none of the VOO phenolic compounds disappeared in flavored oils. An increase in some phenolic compounds, already present in VOO, as well as the presence of new compounds, were observed. In fact, flavored oils showed an increase in vanillin (peak 5), $p$-coumaric acid (peak 6), luteolin (peak 14), apigenin (peak 15), an unidentified peak at a retention time (RT) at $40 \mathrm{~min}$ (peak b: non-flavonoid, not detected at $360 \mathrm{~nm}$ ), and an unidentified peak at RT 50 min (peak c) already present in VOO.

As reported by other studies, the main phenolic compounds identified in T. mastichina extracts are rosmarinic acid, methoxysalicylic acid, apigenin, kaempferol, luteolin, chlorogenic acid, cafeic acid, and derivatives of luteolin and apigenin [24,27]. The HPLC profiles of standards show that rosmarinic acid has an RT of $31.67 \mathrm{~min}$ and higher absorbance at $320 \mathrm{~nm}$. In flavored samples of our study, rosmarinic acid showed not to be the main phenolic compound transferred from the thyme to the oil (Figure 4). Chlorogenic acid ( $R T=16.97 \mathrm{~min})$, caffeic acid $(\mathrm{RT}=18.8 \mathrm{~min})$, and kaempferol $(\mathrm{RT}=43.13 \mathrm{~min})$, referred to in the literature as present in Thymus mastichina, were not transferred to the oil.

Peaks 10 and 16 are referred in the literature as 3,4-DHPEA-EDA (oleacein or dialdehydic form of elenolic acid linked to hydroxytyrosol) and $p$-HPEA-EA (ligstroside aglycone, aldehyde, and hydroxylic form), respectively [37]. Comparing the profile of unflavored Galega VOO obtained in our study with those from the literature [6], higher amounts of 3,4-DHPEA-EDA and $p$-HPEA-EA were observed in VOO from fruits with low ripening indices, which are characterized by high phenol content and flavor intensity.

The sensory analysis was also performed for the original VOO and flavored oils obtained under the conditions of the central point of the CCRD, either by the addition of T. mastichina in the mill or in the malaxator. These oils were sensory evaluated immediately after extraction and after 6 months of storage (Figure 5). After extraction, Galega VOO exhibited a very low $(<2)$ intensity of ripe fruity (orthonasal and retronasal evaluation), bitterness, and pungency. Moreover, defects ascribed to frostbitten olives (wet wood) were detected by assessors with an intensity lower than 3.5. Therefore, despite chemical quality criteria corresponding to the extra virgin olive oil category (Table 4), due to the identification of this defect, the oil can no longer be classified as EVOO but falls in the 
category of "virgin olive oil". The presence of this sensory defect has already been reported in VOO from fruits after weather-related hazards like frost [49,50]. After 6 months of storage in the dark at $22-23^{\circ} \mathrm{C}$, the defect was perceived with similar intensity; a decrease in the intensity of ripe fruity (orthonasal and retronasal) was registered in VOO, while bitter and pungent attributes were no longer detected.

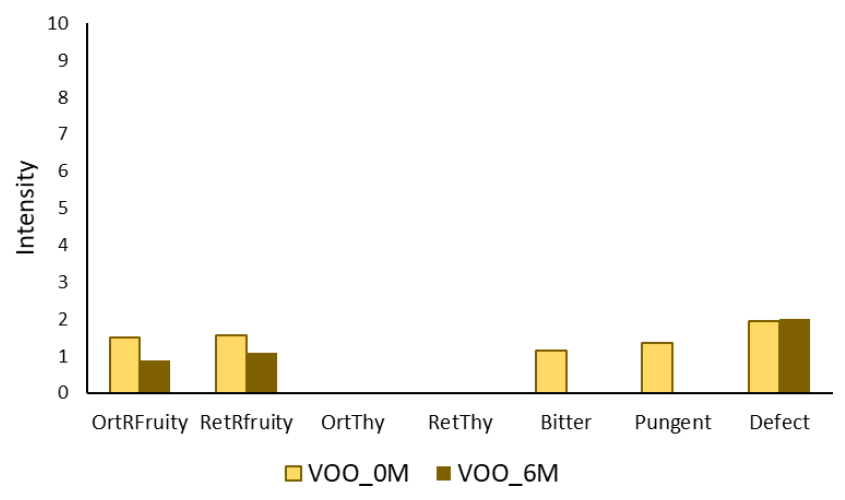

(a)

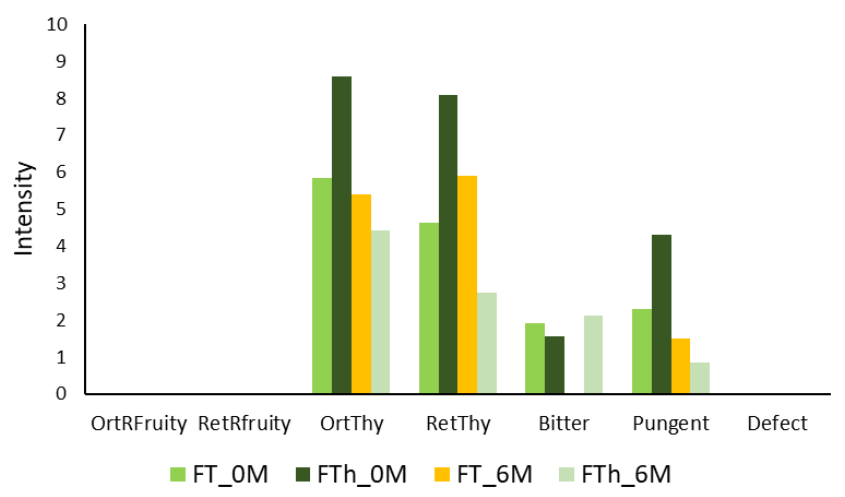

(b)

Figure 5. Sensory evaluation of (a) the VOO without storage (VOO_0M) and after 6 months storage at $22-23^{\circ} \mathrm{C}$ in the dark (VOO_6 M), and of (b) thyme flavored oils in the malaxation step (FT_0M) and in the hammer mill (FTh_0M) without storage and after 6 months storage at $22-23^{\circ} \mathrm{C}$ in the dark (FT_6 M and FTh_6M, respectively). OrtRFruity—orthonasal ripe olive fruity; RetRfruity—retronasal ripe fruity; OrtThy—orthonasal thyme; RetThy—retronasal thyme.

In the flavored oils with Thymus mastichina, the defect of "wet wood" perceived in VOO was not detected. A thyme flavor (orthonasal and rethonasal), with very high intensity $(\geq 8)$ for the hammer mill co-processed oils, and of intensity 5-6, in malaxator co-processed flavored oils, was registered. Moreover, the olive fruity (orthonasal and rethonasal) notes, characteristic of EVOO, were almost absent in thyme-flavored oils. These results indicate that strong changes in the volatile fraction occurred due to the co-processing of olives with thyme, as previously reported by others [51].

After 6 months of storage, no defects were detected in flavored oils. However, a decrease in thyme flavor was observed in both flavored oils, being more pronounced in the oil flavored by the addition of thyme in milling. The bitter taste had similar intensity in both fresh flavored oils. After 6 months of storage, the bitter taste was absent in the flavored oil with thyme addition during malaxation, while its initial intensity was maintained in the flavored oil with thyme addition in milling. Concerning the initial intensity of pungency, it was higher in the flavored oil obtained by thyme addition in milling, but, at the end of the storage experiment, the intensity of this attribute was similar in both flavored oils.

In conclusion, the flavored oil obtained by co-processing with T. mastichina in the mill showed higher initial intensity scores for positive attributes but, after 6 months of storage, its thyme flavor was less intense than that of the oil obtained by co-processing with thyme addition in the malaxator.

In Figure 6, the results of oxidative stability (OS) of VOO and flavored oils by coextraction with T. mastichina added either in the mill or in the malaxator are presented. Co-processing with the addition of thyme in a hammer mill (FTh) improves the OS of the flavored oils (14.07 h in VOO vs. $19.03 \mathrm{~h}$ in flavored oil), while no significant differences were found between VOO and thyme flavored oils in the malaxation step (FT) (14.30 h). After six months of storage, the oils showed a significant decrease in OS. No differences were observed between the VOO and the flavored oil with the addition of thyme in malaxation (c.a. $10.3 \mathrm{~h}$ ), but the OS of the flavored oil obtained by co-extraction with T. mastichina added in the mill was higher, with a value of $16.06 \mathrm{~h}$ (corresponding to a $15.6 \%$ reduction after 6 months of storage). 


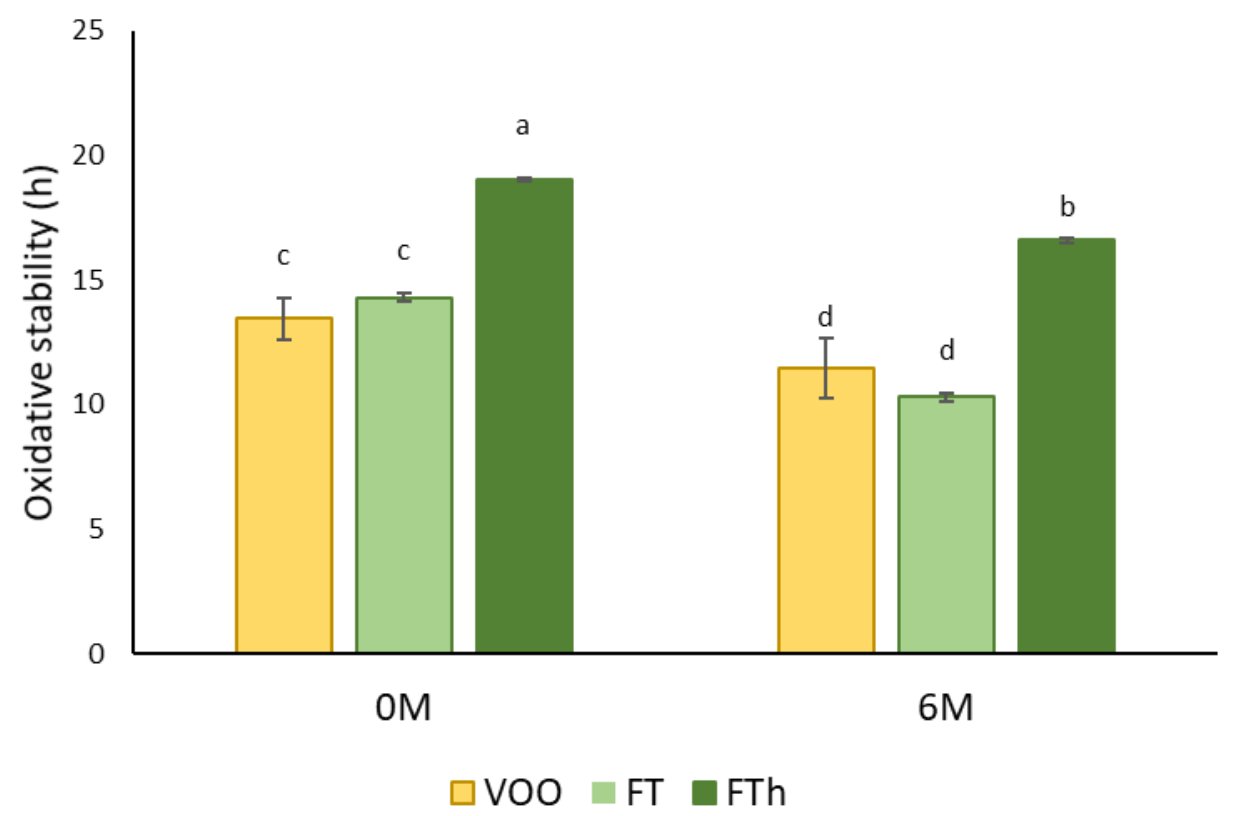

Figure 6. Oxidative stability (hour) of VOO and thyme flavored oils obtained by co-extraction in the malaxation (FT) or in the mill (FTh) at time $0(0 \mathrm{M})$ and after 6 months of storage $(6 \mathrm{M})$ at $22-23^{\circ} \mathrm{C}$ in the dark (different letters of each bar $(a, b, c, d)$ indicate significant differences in the oxidative stability of the oils at $p<0.05$ according to Tukey test).

In Rubió et al. [52], the addition of Thymus zygis extracts significantly improved the oxidative stability of oils when compared to VOO, while Issaoui et al. [47] only detected a nonsignificant increase in OS of flavored oils. Conversely, Issaoui et al. [53] found that the oxidative stability of oils decreased with the addition of thyme, regardless of the concentration added (20 to $80 \mathrm{~g} / \mathrm{kg}$ ).

Depending on several factors, such as the type, the level, and the method of incorporation of the flavoring agent, the initial properties of the olive oil, as well as the storage conditions, results in increasing or decreasing trends in OS have been reported $[10,16,54-56]$. Our results confirm that direct malaxation of the olive paste with thyme or its addition in the hammer mill is a technique that is easy to carry out. Moreover, it does not include any additional unit operation to the conventional olive oil extraction process and is faster than infusion. In addition, both flavoring techniques are conventional green processes that do not require the use of any organic solvents [13].

\section{Conclusions}

Consumer's attitude towards olive oil is changing. Their search for different flavored oils that match several food pairings is an opportunity for the olive oil sector. Thus, the research on developing adequate technologies to produce these novel oils, presenting adequate sensory properties, improved biological value, and shelf-life stability, is of utmost importance for the olive oil industry. Although different techniques can be used, some of them consisting of the incorporation of the flavoring agent in the olive oil may have a deleterious effect on nutritional and shelf-life characteristics. This study showed the feasibility of sustainably producing new high-value products obtained with oils from autochthonous olive cultivars using natural resources. Olive oils obtained from overripe olives, presenting a slight aroma and low amounts of bioactive phenolic compounds, can be highly valorized by co-extraction with thyme. The optimization of co-extraction and storage studies is a good way to evaluate the main effects of the addition of thyme. The co-processing of ripe olives with T. mastichina added, either in the milling or in the malaxation operations, showed to be a feasible and easy technique to obtain flavored oils with intense thyme sensory notes and without sensory defects that were present in the VOO extracted from the same olives. Considering chemical quality criteria, these flavored oils 
have the characteristics of $\mathrm{VOO}$, but they cannot have this classification due to legislation issues. Under optimized co-processing conditions, flavored oils presented higher phenolic contents, and higher biologic value, than the non-flavored VOO. The flavored oil obtained by co-processing with T. mastichina addition in the mill showed higher oxidative stability than the VOO and the co-processed oil with thyme addition in the malaxator, even after six-month storage in the dark.

Author Contributions: Conceptualization, F.P. and S.F.-D.; methodology, F.P., M.M., L.L.M., S.F.-D.; formal analysis, M.R., F.P., M.M.; investigation, M.R., F.P.; data curation, F.P., S.F.-D., M.R.; writingoriginal draft preparation, F.P., M.R., S.F.-D.; writing-review and editing, F.P., M.M., L.L.M., S.F.-D.; supervision, F.P., S.F.-D.; project administration, F.P. All authors have read and agreed to the published version of the manuscript.

Funding: This work was funded by the Fundação para a Ciência e a Tecnologia (FCT), Portugal, through the research unit LEAF-Linking Landscape, Environment, Agriculture and Food Research Centre (UIDB/04129/2020).

Institutional Review Board Statement: Not applicable.

Informed Consent Statement: Not applicable.

Data Availability Statement: Data are available upon request to the authors.

Acknowledgments: The authors thank Conceição Vitorino and Cecilia Gouveia, for the excellent technical assistance, Paula Gonçalves for the help in some of the experimental determinations, the Biotech Plant Lab of Beira Interior, Castelo Branco, Portugal, and the LEAF-Linking Landscape, Environment, Agriculture, and Food Research Centre (UIDP/04129/2020).

Conflicts of Interest: The authors declare no conflict of interest.

\section{References}

1. Servili, M.; Selvaggini, R.; Esposto, S.; Taticchia, A.; Montedoro, G.F.; Morozzib, G. Health and sensory properties of virgin olive oil hydrophilic phenols: Agronomic and technological aspects of production that affect their occurrence in the oil. J. Chromatogr. A 2004, 1054, 113-127. [CrossRef]

2. Cornwell, D.G.; Ma, J. Nutritional Benefit of Olive Oil: The Biological Effects of Hydroxytyrosol and Its Arylating Quinone Adducts. J. Agric. Food Chem. 2008, 56, 8774-8786. [CrossRef]

3. Cicerale, S.; Lucas, L.; Keast, R. Biological Activities of Phenolic Compounds Present in Virgin Olive Oil. Int. J. Mol. Sci. 2010, 11, 458-479. [CrossRef] [PubMed]

4. Psaltopoulou, T.; Kosti, R.I.; Haidopoulos, D.; Dimopoulos, M.; Panagiotakos, D.B. Olive oil intake is inversely related to cancer prevalence: A systematic review and a meta-analysis of 13,800 patients and 23,340 controls in 19 observational studies. Lipids Health Dis. 2011, 10, 127. [CrossRef]

5. Bendini, A.; Cerretani, L.; Carrasco-Pancorbo, A.; Caravaca, A.M.G.; Segura-Carretero, A.; Fernández-Gutiérrez, A.; Lercker, G. Phenolic Molecules in Virgin Olive Oils: A Survey of Their Sensory Properties, Health Effects, Antioxidant Activity and Analytical Methods. An Overview of the Last Decade. Molecules 2007, 12, 1679-1719. [CrossRef]

6. Peres, F.; Martins, L.L.; Mourato, M.; Vitorino, C.; Antunes, P.; Ferreira-Dias, S. Phenolic compounds of 'Galega Vulgar' and 'Cobrançosa' olive oils along early ripening stages. Food Chem. 2016, 211, 51-58. [CrossRef]

7. Wani, T.A.; Masoodi, F.A.; Gani, A.; Baba, W.N.; Rahmanian, N.; Akhter, R.; Wani, I.A.; Ahmad, M. Olive oil and its principal bioactive compound: Hydroxytyrosol-A review of the recent literature. Trends Food Sci. Technol. 2018, 77, 77-90. [CrossRef]

8. Regulation (EC) No 1924/2006 of the European Parliament and of the Council of 20 December 2006 on Nutrition and Health Claims Made on Foods. 2006. Available online: http:/ / data.europa.eu/eli/reg/2006/1924/oj (accessed on 4 January 2021).

9. Commission Regulation (EU) No 432/2012 of 16 May 2012 Establishing a List of Permitted Health Claims Made on Foods, Other than Those Referring to the Reduction of Disease Risk and to Children's Development and Health. 2012. Available online: http:/ / data.europa.eu/eli/reg/2012/432/oj (accessed on 4 January 2021).

10. Baiano, A.; Terracone, C.; Gambacorta, G.; Notte, E.L. Changes in Quality Indices, Phenolic Content and Antioxidant Activity of Flavored Olive Oils during Storage. J. Am. Oil Chem. Soc. 2009, 86, 1083. [CrossRef]

11. Mannina, L.; D'Imperio, M.; Gobbino, M.; D'Amico, I.; Casini, A.; Emanuele, M.C.; Sobolev, A.P. Nuclear magnetic resonance study of flavoured olive oils. Flavour Fragr. J. 2012, 27, 250-259. [CrossRef]

12. Caporaso, N.; Paduano, A.; Nicoletti, G.; Sacchi, R. Capsaicinoids, antioxidant activity, and volatile compounds in olive oil flavored with dried chili pepper (Capsicum annuum). Eur. J. Lipid Sci. Technol. 2013, 115, 1434-1442. [CrossRef] 
13. Caponio, F.; Durante, V.; Varva, G.; Silletti, R.; Previtali, M.A.; Viggiani, I.; Squeo, G.; Summo, C.; Pasqualone, A.; Gomes, T.; et al. Effect of infusion of spices into the oil vs. combined malaxation of olive paste and spices on quality of naturally flavoured virgin olive oils. Food Chem. 2016, 202, 221-228. [CrossRef]

14. Reboredo-Rodríguez, P.; Figueiredo-González, M.; González-Barreiro, C.; Simal-Gándara, J.; Salvador, M.D.; Cancho-Grande, B.; Fregapane, G. State of the Art on Functional Virgin Olive Oils Enriched with Bioactive Compounds and Their Properties. Int. J. Mol. Sci. 2017, 18, 668. [CrossRef] [PubMed]

15. González-Gamallo, S.; Salvador, M.D.; Fregapane, G. Design and Characteristics of Novel Sensory and Nutritionally Oriented Olive, Seed, and Nut Virgin Oils' Blendings. Eur. J. Lipid Sci. Technol. 2021, 123, 2100008. [CrossRef]

16. Cherif, M.; Rodrigues, N.; Veloso, A.C.A.; Zaghdoudi, K.1.; Pereira, J.A.; Peres, A.M. Kinetic-thermodynamic study of the oxidative stability of Arbequina olive oils flavored with lemon verbena essential oil. LWT 2021, 140, 110711. [CrossRef]

17. Sacchi, R.; Della Medaglia, D.; Paduano, A.; Caporaso, N.; Genovese, A. Characterisation of lemon-flavoured olive oils. LWT Food Sci. Technol. 2017, 79, 326-332. [CrossRef]

18. Cerretani, L.; Bendini, A.; Poerio, A.; Toschi, T.G. Citric acid as co-adjuvant: Improvement of the antioxidant activity of edible olive oils. Agro Food Ind. Hi-Tech 2008, 19, 64-66.

19. Clodoveo, M.L.; Dipalmo, T.; Crupi, P.; Durante, V.; Pesce, V.; Maiellaro, I.; Lovece, A.; Mercurio, A.; Laghezza, A.; Corbo, F.; et al. Comparison Between Different Flavored Olive Oil Production Techniques: Healthy Value and Process Efficiency. Plant Foods Hum. Nutr. 2016, 71, 81-87. [CrossRef]

20. Ascrizzi, R.; Taglieri, I.; Sgherri, C.; Flamini, G.; Macaluso, M.; Sanmartin, C.; Venturi, F.; Quartacci, M.F.; Pistelli, L.; Zinnai, A. Nutraceutical Oils Produced by Olives and Citrus Peel of Tuscany Varieties as Sources of Functional Ingredients. Molecules 2019, 24, 65. [CrossRef]

21. Ergönül, P.G.; Sánchez, S. Evaluation of polycyclic aromatic hydrocarbons content in different types of olive and olive pomace oils produced in Turkey and Spain. Eur. J. Lipid Sci. Technol. 2013, 115, 1078-1084. [CrossRef]

22. Bendini, A.; Di Lecce, G.; Valli, E.; Barbieri, S.; Tesini, F.; Gallina Toschi, T. Olive oil enriched in lycopene from tomato by-product through a co-milling process. Int. J. Food Sci. Nutr. 2015, 66, 371-377. [CrossRef]

23. Méndez-Tovar, I.; Sponza, S.; Asensio-S-Manzanera, M.C.; Novak, J. Contribution of the main polyphenols of Thymus mastichina subsp. mastichina to its antioxidant properties. Ind. Crop. Prod. 2015, 66, 291-298. [CrossRef]

24. Taghouti, M.; Martins-Gomes, C.; Schäfer, J.; Santos, J.A.; Bunzel, M.; Nunes, F.M.; Silva, A.M. Chemical Characterization and Bioactivity of Extracts from Thymus mastichina: A Thymus with a Distinct Salvianolic Acid Composition. Antioxidants 2020, 9, 34. [CrossRef]

25. Pardo-de-Santayana, M.; Tardío, J.; Blanco, E.; Carvalho, A.M.; Lastra, J.J.; San Miguel, E.; Morales, R. Traditional knowledge of wild edible plants used in the northwest of the Iberian Peninsula (Spain and Portugal): A comparative study. J. Ethnobiol. Ethnomedicine 2007, 3, 27. [CrossRef] [PubMed]

26. Cunha, A.P.; Roque, O.R. Especiarias e Plantas Condimentares. Origem, Composição e Utilizações; Fundação Calouste Gulbenkian: Lisboa, Portugal, 2015.

27. Delgado, T.; Marinero, P.; Asensio, S.; Manzanera, M.C.; Asensio, C.; Herrero, B.; Pereira, J.A.; Ramalhosa, E. Antioxidant activity of twenty wild Spanish Thymus mastichina L. populations and its relation with their chemical composition. LWT-Food Sci. Technol. 2014, 57, 412-418. [CrossRef]

28. Haaland, P.D. Experimental Design in Biotechnology; Marcel Dekker Inc.: New York, NY, USA, 1989.

29. Montgomery, D.C. Design and analysis of Experiments, 3rd ed.; John Wiley \& Sons: New York, NY, USA, 2017.

30. ISO 661. Animal and Vegetable Fats and Oils-Preparation of Test Sample; ISO: Geneve, Switzerland, 2003.

31. Peres, F.; Martins, L.L.; Ferreira-Dias, S. Laboratory-scale optimization of olive oil extraction: Simultaneous addition of enzymes and microtalc improves the yield. Eur. J. Lipid Sci. Technol. 2014, 116, 1054-1062. [CrossRef]

32. Pizarro, M.L.; Becerra, M.; Sayago, A.; Beltrán, M.; Beltrán, R. Comparison of Different Extraction Methods to Determine Phenolic Compounds in Virgin Olive Oil. Food Anal. Methods 2013, 6, 123-132. [CrossRef]

33. Peres, F.; Talhinhas, P.; Afonso, H.; Alegre, H.; Oliveira, H.; Ferreira-Dias, S. Olive Oils from Fruits Infected with Different Anthracnose Pathogens Show Sensory Defects Earlier Than Chemical Degradation. Agronomy 2021, 11, 1041. [CrossRef]

34. Pokorny, J.; Kalinová, L.; Dysseler, P. Determination of Chlorophyll pigments in Crude Vegetable Oils. Pure Appl. Chem. 1995, 67, 1781-1787.

35. Official Journal of the European Union. Commission Delegated Regulation (EU) No 2019/1604 of 27 September 2019 amending Regulation (EEC) No 2568/91 on the Characteristics of Olive Oil and Olive-Residue Oil and on the Relevant Methods of Analysis; Official Journal of the European Union: Brussels, Belgium, 2019; Volume L250, pp. 14-48. Available online: https:/ / eur-lex.europa.eu/ legal-content/EN/TXT/PDF/?uri=CELEX:32019R1604\&from=EN (accessed on 4 January 2021).

36. Cerretani, L.; Salvador, M.D.; Bendini, A.; Fregapane, G. Relationship Between Sensory Evaluation Performed by Italian and Spanish Official Panels and Volatile and Phenolic Profiles of Virgin Olive Oils. Chem. Percept. 2008, 1, 258-267. [CrossRef]

37. IOC. Determination of Biophenols in Olive Oils by HPLC. COI/T20/DOC.29. 2009. Available online: https://www.oelea. de/downloads/COI-T20-DOC-29-2009-DETERMINATION-OF-BIOPHENOLS-IN-OLIVE-OILS-BY-HPLC.pdf (accessed on 4 January 2021).

38. Pirisi, F.M.; Cabras, P.; Cao, C.F.; Migliorini, M.; Muggelli, M. Phenolic Compounds in Virgin Olive Oil. 2. Reappraisal of the Extraction, HPLC Separation, and Quantification Procedures. J. Agric. Food Chem. 2000, 48, 1191-1196. [CrossRef] [PubMed] 
39. Barros, L.; Carvalho, A.M.; Ferreira, I.C.F.R. From famine plants to tasty and fragrant spices: Three Lamiaceae of general dietary relevance in traditional cuisine of Trás-os-Montes (Portugal). LWT-Food Sci. Technol. 2011, 44, 543-548. [CrossRef]

40. Kassegn, H.H.; Mekelle, E.P. Inorganic and phytochemical content analysis of the wild abyssinian thyme spice. Food Sci. Qua. Manage. 2016, 82-85.

41. Kuçukbay, F.; Kuyumcu, E. Determination of trace element contents of Thymus species from Turkey. Turk. J. Chem. 2010, 34, 911-920.

42. Squeo, G.; Difonzo, G.; Summo, C.; Crecchio, C.; Caponio, F. Study of the influence of technological coadjuvants on enzyme activities and phenolic and volatile compounds in virgin olive oil by a response surface methodology approach. LWT 2020, 133, 109887. [CrossRef]

43. Sadkaoui, A.; Jiménez, A.; Pacheco, R.; Beltrán, G. Micronized natural talc affects the proteins and pectic cell wall polysaccharides during "Hojiblanca" virgin olive oil extraction. Eur. J. Lipid Sci. Technol. 2017, 119, 1600039. [CrossRef]

44. Gambacorta, G.; Faccia, M.; Pati, S.; Lamacchia, C.; Baiano, A.; La Notte, E. Changes in the chemical and sensorial profile of extravirgin olive oils flavored with herbes and spices during storage. J. Food Lipids 2007, 14, 202-215. [CrossRef]

45. Rodrigues, N.; Casal, S.; Pinho, T.; Peres, A.M.; Bento, A.; Baptista, P.; Pereira, J.A. Ancient olive trees as a source of olive oils rich in phenolic compounds. Food Chem. 2018. [CrossRef] [PubMed]

46. Ayadi, M.A.; Grati-Kamoun, N.; Attia, H. Physico-chemical change and heat stability of extra virgin olive oils flavoured by selected Tunisian aromatic plants. Food Chem. Toxicol. 2009, 47, 2613-2619. [CrossRef] [PubMed]

47. Issaoui, M.; Flamini, G.; Souid, S.; Bendini, A.; Barbieri, S.; Gharbi, I.; Toschi, T.G.; Cioni, P.L.; Hammami, M. How the Addition of Spices and Herbs to Virgin Olive Oil to Produce Flavored Oils Affects Consumer Acceptance. Nat. Prod. Commun. $2016,11$. [CrossRef]

48. Diamantakos, P.; Giannara, T.; Skarkou, M.; Melliou, E.; Magiatis, P. Influence of Harvest Time and Malaxation Conditions on the Concentration of Individual Phenols in Extra Virgin Olive Oil Related to Its Healthy Properties. Molecules 2020, $25,2449$. [CrossRef]

49. Guillaume, C.; Ravetti, L.; Gwyn, S. Characterisation of Phenolic Compounds in Oils Produced from Frosted Olives. J. Am. Oil Chem. Soc. 2010, 87, 247-254. [CrossRef]

50. García-Vico, L.; García-Rodríguez, R.; Sanz, C.; Pérez, A.G. Biochemical aspects of olive freezing-damage: Impact on the phenolic and volatile profiles of virgin olive oil. LWT 2017, 86, 240-246. [CrossRef]

51. Baiano, A.; Previtali, M.A.; Viggiani, I.; Varva, G.; Squeo, G.; Paradiso, V.M.; Summo, C.; Gomes, T.; Caponio, F. As oil blending affects physical, chemical, and sensory characteristics of flavoured olive oils. Eur. Food Res. Technol. 2016, 242, 1693-1708. [CrossRef]

52. Rubió, L.; Motilva, M.-J.; Macià, A.; Ramo, T.; Romero, M.-P. Development of a Phenol-Enriched Olive Oil with Both Its Own Phenolic Compounds and Complementary Phenols from Thyme. J. Agric. Food Chem. 2012, 60, 3105-3112. [CrossRef] [PubMed]

53. Issaoui, M.; Flamini, G.; Hajaij, M.E.; Cioni, P.L.; Hammami, M. Oxidative Evolution of Virgin and Flavored Olive Oils under Thermo-oxidation Processes. J. Am. Oil Chem. Soc. 2011, 88, 1339-1350. [CrossRef]

54. Bobiano, M.; Rodrigues, N.; Madureira, M.; Dias, L.G.; Veloso, A.C.A.; Pereira, J.A.; Peres, A.M. Unmasking Sensory Defects of Olive Oils Flavored with Basil and Oregano Using an Electronic Tongue-Chemometric Tool. J. Am. Oil Chem. Soc. 2019, 96, 751-760. [CrossRef]

55. Khemakhem, I.; Yaiche, C.; Ayadi, M.A.; Bouaziz, M. Impact of Aromatization by Citrus limetta and Citrus sinensis Peels on Olive Oil Quality, Chemical Composition and Heat Stability. J. Am. Oil Chem. Soc. 2015, 92, 701-708. [CrossRef]

56. Taoudiat, A.; Djenane, D.; Ferhat, Z.; Spigno, G. The effect of Laurus nobilis L. essential oil and different packaging systems on the photo-oxidative stability of Chemlal extra-virgin olive oil. J. Food Sci. Technol. 2018, 55, 4212-4222. [CrossRef] 